\title{
Medicinal Plants with Prospective Benefits in the Management of Peptic Ulcer Diseases in Ghana
}

\author{
Mavis Boakye-Yiadom (D), ${ }^{1,2}$ Doris Kumadoh $\left(\mathbb{D},,^{3,4}\right.$ Emmanuel Adase $\mathbb{D}^{4},{ }^{4}$ and Eric Woode $\mathbb{D}^{5}$ \\ ${ }^{1}$ Clinical Research Department, Centre for Plant Medicine Research, Mampong-Akuapem, Ghana \\ ${ }^{2}$ Department of Pharmacology, Faculty of Pharmacy \& Pharmaceutical Sciences, College of Health Sciences, Kwame Nkrumah \\ University of Science and Technology, Kumasi, Ghana \\ ${ }^{3}$ Department of Pharmaceutics, Centre for Plant Medicine Research, Mampong-Akuapem, Ghana \\ ${ }^{4}$ Department of Production, Centre for Plant Medicine Research, Mampong-Akuapem, Ghana \\ ${ }^{5}$ Department of Pharmacology and Toxicology, School of Pharmacy, University of Health and Allied Sciences, Private Mail Bag, \\ Volta Region, Ghana
}

Correspondence should be addressed to Mavis Boakye-Yiadom; magaby2752001@gmail.com

Received 9 February 2021; Revised 11 April 2021; Accepted 16 April 2021; Published 6 May 2021

Academic Editor: Michael Buenor Adinortey

Copyright ( 2021 Mavis Boakye-Yiadom et al. This is an open access article distributed under the Creative Commons Attribution License, which permits unrestricted use, distribution, and reproduction in any medium, provided the original work is properly cited.

\begin{abstract}
Background. The growth or multiplication of harmful microorganisms in addition to harmful human activities has led to many disorders in humans. Consequently, there is a search for medications to treat these disorders. Interestingly, medicines of plant origin are known to be among the most attractive sources of new drugs and have shown promising results in the treatment of various diseases including peptic ulcers. This review, therefore, is aimed at obtaining knowledge on some Ghanaian ethnomedicinal plants used to treat peptic ulcers, their folkloric uses, their phytochemicals, and their antiulcer and related pharmacological activities as well as finding areas for prospective studies.Methods. Published peer-reviewed articles on ethnomedicinal plants used for the management of peptic ulcers in Ghana from 1967 to 2020 were sourced and used for the study. Results. In this review, 13 plants were identified which belong to 10 different families including Sapindaceae, Apocynaceae, and Bignoniaceae. The parts most often used for most preparations were the leaves (53\%), followed by stem bark and roots (both having the same percentage of use of $17.6 \%)$, the whole plant (5.9\%), and the rhizomes (5.9\%). Azadirachta indica was the only plant that had undergone some patient studies in addition to animal studies. Conclusion. A discussion of various antiulcer activity studies using ulcer models carried out on selected medicinal plants used for the management of peptic ulcer disease in addition to brief information on their folkloric uses and their phytochemical and other pharmacological properties is presented. These medicinal plants may be used in developing herbal products for the management of peptic ulcer disease.
\end{abstract}

\section{Introduction}

Peptic ulcer remains one of the gastrointestinal disorders that has affected many people worldwide over the centuries with over $5-10 \%$ of the world population generally affected. This condition occurs when the endothelial lining of the oesophagus, stomach, and/or duodenum is damaged. Also, insufficient gastric mucosal resistance may lead to peptic ulcers [1]. Some factors that cause peptic ulcers include $H$. pylori infection, alcohol consumption, tobacco smoking, psychological stress, some hereditary conditions, and drug abuse mostly with nonsteroidal anti-inflammatory drugs (NSAIDs) such as aspirin and ibuprofen [2]. Several orthodox drugs have been manufactured to combat this disorder. Most of these drugs are costly and have intolerable side effects when taken. Some orthodox drugs employed in the treatment of this disorder include histamine $\left(\mathrm{H}_{2}\right)$ receptor antagonists, proton pump inhibitors, cytoprotectants, antacids, and prostaglandin analogues $[3,4]$. 
Herbal medicines have been used in treating various diseases throughout the millennia before the discovery of most conventional medicines. Due to this, herbal medicines have been perceived to have healthier cultural acceptability and less toxic and decreased antagonistic effects [4]. Several prospective medicinal plants for peptic ulcer treatment have been studied and reported in literature globally. Lakshmi et al. reported on some medicinal plants including Allophylus serratus Kurz, Cissus quadrangularis, Ocimum sanctum Linn, Mangifera indica L., Zingiber officinale Roscoe, Butea frondosa Roxb. L., Glycyrrhiza glabra L., Solanum nigrum L., and Terminalia chebula Retz [5]. Also, medicinal plants such as Cynodon dactylon, Azadirachta indica, Glycyrrhiza glabra, Swietenia mahagoni, Bauhinia purpurea L., Ficus religiosa, Melastoma malabathricum, Ocimum sanctum, Spondias mombin L., Eruca sativa, and Osyris quadripartite have been reported as possessing some form of antiulcer activity upon investigation in antiulcer testing models [6-13]. A triple herbal therapy comprised of Enterica, Dyspepsia decoctions, and Natural Pain Killer (NPK 500) capsules manufactured by the Centre for Plant Medicine Research (CPMR) is currently used in the management of peptic ulcer disease at the CPMR out-patient clinic in Ghana. These three products contain medicinal plants such as Carapa procera, Trichilia monadelpha, Persea americana, Trema orientalis, Momordica charantia, Vernonia amygdalina, Cassia siebieriana, Citrus aurantifolia, Bidens pilosa, Morinda lucida, Maytenus senegalensis, Psidium guajava, Cnestis ferruguinea, Spondias mombin, and Latana camara. In this review, efforts have been made to present thirteen (13) prospective Ghanaian medicinal plants with their antiulcer activities. These medicinal plants are Chromolaena odorata, Blighia sapida, Cyperus rotundus, Magnifera indica, Azadirachta indica, Alchornea cordifolia, Calotropis procera, Hoslundia opposita, Kigelia africana, Spathodea campanulata, Strophanthus hispidus, Zingiber officinale, and Paullinia pinnata. These medicinal plants were selected due to their folkloric use in the treatment of peptic ulcers and availability in Ghana.

\section{Literature Review Approach and Method Adopted}

The information on ethnomedicinal plants used for the management of peptic ulcers in Ghana was obtained from published peer-reviewed articles on the plants. Electronic databases accessed included Google Scholar, PubMed, Web of Science, and Scopus. The major search terms used were "Plant names AND peptic ulcer," "Plant names AND Helicobacter pylori," "Plant names AND gastric ulcer," "Plant names AND anti peptic ulcer," and "Plant names and duodenal ulcer." All the articles obtained were reviewed to get the needed information on ethnomedicinal plants used in Ghana for the management of peptic ulcers. A review was conducted on all of ethnomedicinal plants concerning their pharmacological activities (antiulcer activities) and active compounds that have been used in the management of peptic ulcers. Attempts at retrieving available preclinical and clinical works done on each plant were also done. The in vivo or in vitro methods employed by the researchers on each plant in their studies for peptic ulcer and the mechanism of action of each plant were assessed from the electronic data obtained. All the retrieved articles used were acknowledged and other evidence significant to each plant was provided such as type of plant extract, plant part used, scientific names, and antiulcer models.

\section{Results}

3.1. Chromolaena odorata (L.) R.M. King \& H. Rob. Chromolaena odorata ( $C$. odorata) from the Asteraceae family is a seasonal perennial flowering shrub that grows up to $2.5 \mathrm{~m}$ tall. The plant has a soft stem with hairy leaves which give an aromatic odour when prepared in a decoction form. C. odorata is mostly dominant in the tropical and subtropical areas and is domesticated in some parts of Asia, West Africa, and parts of Australia [14]. Local names for C. odorata include Siam weed, baby tea, devil weed, and paraffin bush [15]. C. odorata is traditionally used to treat diabetes, wounds, malaria, diarrhoea, dysentery, skin diseases, and toothache [16-18]. Several reviews have also shown that the plant has analgesic, antibacterial, antioxidative, anti-inflammatory, antifungal, and antidiabetic activities [19-24]. Aqueous and methanol extracts of the leaf have been investigated and found to have phytochemicals such as flavonoids, tannins, steroids, terpenoids, and cardiac glycosides. Alkaloids have also been seen in the methanolic extract [24-27].

The extract from the fresh leaves has been used for the treatment of various ulcers [28]. An evaluation of the cytoprotective effects of the ethanolic and aqueous extracts of $C$. odorata in combination with honey using absolute ethanol plus hydrochloric acid $(\mathrm{HCl})$ for the induction of gastric wounds in Sprague-Dawley rats has been conducted. Results obtained indicated that $C$. odorata and honey may be useful in treating induced gastric membrane injury [29]. This could be attributed to the dominant anti-inflammatory and antioxidant properties of C. odorata $[20,22]$. A study involving an investigation of the antiulcer effect of a combination of Chromolaena odorata and Ocimum gratissimum leaf extracts was reported to show a marked positive effect in the treatment of duodenal ulcer using the ethanol-induced ulcer model in adult albino Wistar rats. Pretreatment with the combined extracts was seen to minimise the formation of duodenal lesions in a dose-dependent fashion [30]. Paul et al. have reported on the antiulcer activities of $C$. odorata where stomach ulcer induced in rats using absolute ethanol was treated with aqueous extract from C. odorata [31]. A major reduction in stomach lesions using the ulcer index and histopathological data was observed in the treatment rats' group compared with the disease control group. The antiulcer action may be due to phytochemical constituents such as polyphenolic compounds and flavonoids contained in $C$. odorata [31]. Although the antiulcer activity of C. odorata has been confirmed, a report from a toxicity study conducted by Anyanwu et al. using the ethanolic extract of $C$. odorata at doses of $50 \mathrm{mg} / \mathrm{kg}, 100 \mathrm{mg} / \mathrm{kg}$, and $250 \mathrm{mg} / \mathrm{kg}$ in albino rats indicated an increase in urea and creatinine levels in a dose-dependent manner coupled with the permeation of inflammatory cells and epithelial erosion in histological sections. They, therefore, concluded that uncontrolled use of 
the extract of this plant may have negative effects on the function of the kidney and the histology of the gut [32]. Doses for formulations must therefore be carefully selected with accompanying toxicological evaluations of finished products containing $C$. odorata extracts.

3.2. Alchornea cordifolia (Schumach. \& Thonn.) Müll. Arg. Alchornea cordifolia (A. cordifolia) from the family Euphorbiaceae is found widely in the African continent. It is a small perennial plant that grows up to 8 metres tall in marshy areas [33]. The plant is commonly known as the Christmas bush and propagated through sexual and asexual means. It is mostly used for the treatment and management of several diseases in Ghana. The stem and leaves are used as a folk medicine for the treatment of arthritis and muscle pains, venereal diseases, acute and inflammatory chronic conditions, cancer, ulcers, rheumatism, sores of canker, colds, miscarriage, urogenital infections, and leprosy and as an antidote for snakebite, bronchitis, cough, angina, headache, diarrhea, dysentery, fever, malaria, ringworm, and piles [34-38].

Pharmacological activities have been reported on $A$. cordifolia including analgesic, anxiolytic, anti-inflammatory, antibacterial, antidiabetic, antimicrobial, antimalarial, antiaflatoxicosis, and antioxidant activities [39-42]. Phytochemical analysis of the plant indicated the existence of tannins, terpenoids, glycosides, alkaloids, saponins, and flavonoids [43]. The methanolic extract of $A$. cordifolia leaves at doses of $500 \mathrm{mg} / \mathrm{kg}$ and $1000 \mathrm{mg} / \mathrm{kg}$ body weight was evaluated with two antiulcer testing models (pylorus ligation and $\mathrm{HCI} /$ ethanol-induced) in rats. The results indicated that the methanolic extract at dose of $1000 \mathrm{mg} / \mathrm{kg}$ body weight prevented ulcer formation and caused a marked reduction in gastric juice secretion [44]. Osafanme et al. investigated a polyherbal formulation of the aqueous extract of $A$. cordifolia (EXR-HF2) on indomethacin, ethanol, and histamine ulcer models, and the result revealed that EXR-HF2 had gastroprotective potential which hindered the creation of ulcer induced in all the three ulcer models [45]. The ethanolic extract of $A$. cordifolia leaves has also demonstrated great potential in the treatment and management of gastric ulcers caused by $H$. pylori [46].

3.3. Blighia sapida K.D. Koenig. Blighia sapida (B. sapida) is an evergreen plant that is domesticated in West Africa. It normally grows to about $25 \mathrm{~m}$ high. It belongs to the family Sapindaceae and is commonly referred to as Ackee in English. The fruit from ackee is consumed fresh, roasted, or dried. Some natives use the fruit for soup or sauce in some communities in West Africa [47, 48]. The Blighia sapida tree is used in folk medicine for the management of hernia, yellow fever, malaria, diabetes, dysentery, internal hemorrhage, bleeding piles, epilepsy, oedema, diarrhea, migraine, yaws, and ulcers [49-51]. Ojo et al. assessed the antioxidant and inhibitory properties of the stem bark, characterized the phytochemicals, and concluded that the ethanolic extract of the stem bark possesses the inhibitory effects of $\alpha$-glucosidase and $\alpha$-amylase in addition to its antioxidative effect [52]. The inhibitory effects of the $B$. sapida stem bark extract on the $\alpha$-amylase and $\alpha$-glucosidase actions may be a result of its phytochemical contents such as polyphenols, tannins, and saponins [52]. The root extract of B. sapida has been shown to have a hypoglycaemic effect in normoglycemic rats and ameliorate pancreatic $\beta$-cell dysfunction [53]. The phytochemical constituents of the stem bark include cardiac glycosides, saponins, anthraquinones, flavonoids, alkaloids, phlobatannins, and terpenes [54].

A study conducted by Oreagba et al. to analyse the antiulcer activity of the hydroethanolic leaf extract of Blighia sapida using absolute $\mathrm{HCl}-e t h a n o l$, ethanol, cold-restraint stress, indomethacin, and pylorus ligation ulceration in rats showed that the extract produced dose-relative antiulcer effects [55]. This was evident by the significant protection of the gastric membrane. The hydroethanolic leaf extract also markedly reduced the ulcer index in the cold-restraint stress and pyloric ligation-induced ulcer models compared to cimetidine and omeprazole standard drugs. Also, the levels of the $\mathrm{pH}$, gastric juice volume, free acidity, and acidity determined in the ulcer model induced by pylorus ligation demonstrated that pretreatment with the hydroethanolic leaf extract of Blighia sapida safeguarded gastric mucosa by marked reduction of acid secretion and the ulcer index in gastric membrane injury. B. sapida may therefore have antisecretory, gastroprotective, and free radical scavenging properties [55].

Adedosu et al. also evaluated the aqueous leaf extract of Blighia sapida on ethanol-induced gastric ulcer in male Wistar rats where animals treated with the extract at doses of $400 \mathrm{mg} / \mathrm{kg}$ body weight showed the maximum inhibition of the ulcer index. Results from the study indicated that Blighia sapida leaves showed ameliorative, antiulcer, and antiinflammatory activities. These exhibited actions may be due to phytochemical constituents in the plant in addition to antisecretive effects of the aqueous extract of Blighia sapida [56].

3.4. Cyperus rotundus L. Cyperus rotundus (C. rotundus), a perennial herb found in the tropical and temperate regions, is from the Cyperaceae family. It is used in folkloric medicine for the management and treatment of malaria, fever, rheumatism, arthritis, pains, and hypertension [57].

The extract of the plant contains some secondary metabolites including tannins, alkaloids, triterpenoids, flavonoids, phenolics, saponins, proteins, essential oils, starch, carbohydrates, and cardiac glycosides [58, 59]. Pharmacological screening confirms that the plant has antiparasitic, antiinflammatory, antirheumatic, antidiabetic, antidiarrhoeal, antifungal, antispasmodic, neuropharmacological, and aphrodisiac properties [60-62].

Cyperus rotundus exhibited gastroprotective potential when tested in Wistar albino rats via the pylorus ligationinduced ulcer model [63]. Also, C. rotundus exhibited an antiulcer property when used at a dose of $500 \mathrm{mg} / \mathrm{kg}$ against the aspirin-induced ulcer model [62]. Mohammed et al. studied the antiulcer effects of the tuber powder of $C$. rotundus at a dose of $1.25 \mathrm{mg} / \mathrm{kg}$ body weight against a histamineinduced gastric ulcer in guinea pigs for 45 minutes and oral administration of $500 \mathrm{mg} / \mathrm{kg}$ against the aspirin-induced gastric ulcer for one hour. From the results obtained, a reduction in the ulcer index was observed in both cases which may be attributed to the secondary metabolites of C. rotundus [64]. 
3.5. Azadirachta indica A. Juss. Azadirachta indica (A. indica), commonly referred to as neem, is from the Meliaceae family. It is an evergreen tree originating from South East Asia which also grows in semitropical and tropical areas globally. It is also found in several African countries. Azadirachta indica is used in folklore medicine for the treatment of intestinal disorders, skin diseases, constipation, respiratory disorders, malaria $[65,66]$, fever, asthma, piles, diabetes, urinary tract infections, scabies, and ringworm [66]. The phytochemical constituents found in A. indica include alkaloids, saponins, tannins, and flavonoids [67]. The reported pharmacological activities on the leaves of Azadirachta indica are comprised of antiulcer, antifungal, anti-inflammatory, antibacterial [68], antiviral, antioxidant, antimutagenic, and antimalarial properties [69]. The antiulcer activity of Azadirachta indica has been reported by Chattopadhyay et al. [70], where the aqueous leaf extract was used to prevent gastric ulcers, oxidative damage, acid secretion, and apoptosis in rats. The antiulcer models employed were pylorus ligation, cold stress, ethanol, and indomethacin-induced models. Results from the ulcer model induced by stress showed the Azadirachta indica extract to be more efficacious than ranitidine but less efficacious than omeprazole. The extract also showed an effective reduction in mercaptomethylimidazoleinduced acid secretion and pylorus ligation and produced an antiulcer function by preventing the secretion of acid through $\mathrm{H}+-\mathrm{K}+-\mathrm{ATPase}$ and by preventing apoptosis and oxidative damage [70]. The alcoholic extract of Azadirachta indica leaves investigated in aspirin-induced gastric ulcers in rats exhibited a reduction in ulcers with pretreatment of the Azadirachta indica extract producing a substantial gastroprotective impact in rats [71]. However, a reduction in ulceration may be due to the enhancement of the prostaglandin and cyclooxygenase pathway which makes the gastric membrane more impervious to damage. Prevention of blockage of mucosal membrane function and enhancement of cytosolic adenosine triphosphate activity, reduction in proton dissipation from surface epithelial cells, and prevention of sodium transport may all contribute to the observed antiulcer activity [72]. Azadirachta indica may also cause enhancements in mucin, surface-active phospholipids, and bicarbonate secretion. It may also prevent injury resulting from free radicals [69]. The antiulcer activity was also evaluated by Bhajoni et al., [10] using the aqueous leaf extract of $A$. indica at doses of 150,300 , and $600 \mathrm{mg} / \mathrm{kg}$ body weight in Wistar rats with three antiulcer models: cold-restraint stress, pylorus ligation, and aspirin. Their study demonstrated that the aqueous extract of $A$. indica showed a marked reduction in the ulcer index in a dose-dependent manner and an increase in percentage inhibition in all models employed compared to the control group using ranitidine as a standard drug. This indicates the likely involvement of the prostaglandin pathway in the medium of the function of $A$. indica. There was also a marked decrease in gastric volume and the free and total acidity in comparison with the control group [10]. Prevention of the production of acid in the stomach and the release of histamine could also cause a reduction in ulceration [73]. A. indica extracts have again been investigated on gastric secretion and gastroduodenal ulcer. The indomethacin-induced ulcer model was investigated by Raji et al. [74] using the aqueous stem bark extract of $A$. indica, at doses between 100 and $800 \mathrm{mg} / \mathrm{kg}$ body weight. Marked reduction in ulcer was seen. Also, oral administration of $250 \mathrm{mg} / \mathrm{kg}$ body weight of $A$. indica in combination with cimetidine $(0.12 \mathrm{mg} / \mathrm{kg}$ body weight $)$ and histamine $(1 \mathrm{mg} / \mathrm{kg}$ body weight) in vivo resulted in effective inhibition of histamine-induced gastric acid secretion. The $A$. indica extract has also been evaluated in Indian patients suffering from gastroduodenal ulcer and acid-related problems. The extract was dispensed at a dosage regimen of $30 \mathrm{mg}$ twice daily for a total of 6 weeks. Results obtained confirm that the bark extract of $A$. indica has therapeutic potential for the management of gastro/duodenal ulcers. The healing process of duodenal ulcers was monitored using endoscopy and barium meal X-ray. The study also revealed that gastric hypersecretion was adequately controlled [75]. The A. indica extract was studied in albino rats and dogs using a chronic ulcer model induced by acetic acid. The results revealed nimbidin, a phytochemical constituent of $A$. indica, may enhance ulcer healing in experimental animals [76].

3.6. Calotropis procera (Aiton) W.T. Aiton. Calotropis procera (C. procera) from the family Apocynaceae is a perennial shrub originating from Asia. It is widely found in Africa; Brazil; and North, Western, and Central India [77]. The plant has several folkloric medicinal uses including the management of fever, asthma, piles, liver disorders, dyspepsia, cold, diarrhea, leprosy, indigestion, ulcers, eczema, skin disease, intestinal worms, diarrhea, rheumatism, pain, cough, spleen disorders, tumors, elephantiasis, and jaundice [77-80]. The phytochemical constituents of the plant such as flavonoids, polyphenolic compounds, stigmasterol, $\beta$-sitosterol, alkaloids, saponins, and tannins have been reported [77]. Pharmacological studies have reported antidiarrheal, antimicrobial, anti-inflammatory, acaricidal, anthelmintic, schizonticidal, insecticidal, and anticancer activities [81, 82]. Antiulcer studies involving the investigation of $C$. procera extract against aspirin- and ethanol-induced ulcer models in albino rats at 200 and $400 \mathrm{mg} / \mathrm{kg}$ doses showed marked antiulcer activity in the open excised rat stomach when compared to the standard drugs [83].

Another investigation of the leaf extract of C. procera, at a dose of $400 \mathrm{mg} / \mathrm{kg}$, produced a cytoprotective effect against ulcer induced by indomethacin in Sprague-Dawley rats [84]. The C. procera leaf extract also showed a reduction in gastric volume and acid accumulation [85]. An investigation of the antiulcer activity in the pylorus ligation model in rats has also shown that the $C$. procera leaf extract caused a reduction in gastric volume [86]. Such promising activities can be linked to the phytoconstituents of each extract. These studies suggest that $C$. procera may have natural potency and could be a promising drug or supplement for the management of peptic ulcers [84]. The antiulcer properties of C. procera investigated in rats using aspirin-induced ulceration showed an effective reduction in ulceration. Hence, the antiulcer properties of the extract of $C$. procera can be attributed to free radical scavenging property, reduction in acid secretion, enhancement of gastric mucosal barrier, and improvement 
in cytoprotection. Marked cytoprotection has also been observed in guinea pigs with the extract of $C$. procera in histamine-induced duodenal ulcers [84].

3.7. Hoslundia opposita Vahl Family. Hoslundia opposita (H. opposita) from the Labiatae family is a scrambling soft shrub growing up to about $1.2-4.5 \mathrm{~m}$ tall with a wide distribution in the southern part of Africa and tropical Africa. H. opposita grows well in both wet and dry areas in Ghana. In folkloric medicine, the plant has been used in remedies of diabetes, cold, malaria, sores, skin diseases, fevers, sore throat, herpes, microbial infections, venereal diseases, epilepsy, wounds, inflammation, and gonorrhea [87-90]. The phytochemical constituents found in the plant include alkaloids, tannins, flavonoids, phenols, terpenoids, saponins, and quinones in both aqueous and ethanolic extracts $[91,92]$. The pharmacological activities that have been reported on H. opposita include antibacterial, antimalarial, anticonvulsant, and antimicrobial activities; it also has antioxidant, CNS depression, hepatoprotective, and insecticidal properties[91-94].

A decoction from the roots and leaves of $H$. opposita is employed orally to manage chronic and deep wounds, stomach ulcer, and dermatitis in some regions of Ghana $[95,96]$. The wound healing activity demonstrated by most plants is linked to the additive or synergistic actions of their constituents [95]. A survey done by Agyare et al. [96] showed that traditional healers used Hoslundia opposita for healing wounds and stomach ulcers. Relative adhesion of the $H$. opposita aqueous extract against Helicobacter pylori was demonstrated in AGS human stomach cells. The result showed strong antiadhesive agents with relative values of $134 \pm 14 \mathrm{mg} / \mathrm{ml}$ and $48 \pm 12 \mathrm{mg} / \mathrm{ml}$ were comparable to a positive control (Abelmoschus esculentus fruit extract) with values of $9 \pm 6 \mathrm{mg} / \mathrm{ml}$, indicating that the aqueous extract of H. opposita may be useful for the treatment of stomach ulcer [95]. The antiulcer activities on H. opposita are scarce; however, essential oils present in the plant may contribute positive effects in the treatment of stomach ulcer pain [97]. It has been found that flavonoids exhibit antimicrobial activity and consequently may significantly help to reduce or prevent wound infections [98].

3.8. Kigelia africana (Lam.) Benth. Kigelia africana (K. africana) is from the Bignoniaceae family and is a perennial tree (sausage tree) growing in the tropics and subtropics of Africa. It is widely spread in the coastal and Savanna Regions of Ghana [99].

The bark, root, and leaf of $K$. africana have been locally used for skin diseases, depression, diabetes, fungal infection, wound, eczema, and bacterial infection [100, 101]. The phytochemical constituents found in K. africana include reducing sugars, saponins, flavonoids, alkaloids, phytosterols, coumarin, naphthoquinones, and glycosides [101-104]. The reported pharmacological properties of the plant include anticancer, antimalaria, antibacterial, anti-inflammatory, and antioxidant properties $[105,106]$. The antiulcer activity of the methanol extract of $K$. africana against gastric injuries induced by aspirin and histamine was reported by Anvesh et al. [107]. The results from their study showed that, after the induction of ulcer, the highest-dose extract $(1000 \mathrm{mg} / \mathrm{kg}$ body weight) recorded a marked decline in the ulcer index much better than that of ranitidine. In Wistar albino rats, after the induction of ulcer, $100 \mathrm{mg} / \mathrm{kg}$ and $400 \mathrm{mg} / \mathrm{kg}$ doses of the K. africana leaf extract administered with aspirin prevented ulceration. The antiulcer activity can be due to the release of prostaglandins that protect the gastric mucosa and possibly free radical scavengers [108]. The methanolic leaf extracts of the plant in aspirin-induced and ethanolinduced ulcer models in animals have been evaluated by Hamamalini et al. [109]. The methanol leaf extract decreased the ulcer index, ulcer score, and the number of ulcers in aspirin-induced and ethanol-induced ulcer models in rats at a dose of $200 \mathrm{mg} / \mathrm{kg}$. The study also demonstrated that the presence of phytochemical constituents contributed to the reduction in the ulcer index in rats. The reduction in ulceration showed by the methanolic extract of $K$. africana leaves with the aspirin-induced ulcer model in rats could be due to the inhibition of changes in the permeability of the gastric mucosa, the penetration (diffusion) of gastric acid, and the release of histamine [110]. Improving the synthesis of prostaglandin and activating cyclooxygenase can also contribute to the activity observed [111]. At a dose of $450 \mathrm{mg} / \mathrm{kg}$ body weight, the ethanolic leaf extract of $K$. africana exhibited cytoprotection in an ethanol-induced ulcer model. There was also a marked decrease in the ulcer index in albino rats in aspirin-induced ulcers equivalent to that of the standard medication, cimetidine [102]. The antiulcer activity on $K$. africana has again been investigated against oxidative stress on ethanol-induced ulcer models in rats. The aqueous leaf extract of the plant orally administered at various dosages after inducing ulcer with ethanol caused a decrease in the ulcer index in a dose-dependent manner. The study, therefore, concluded that the aqueous leaf extract of $K$. africana has antiulcer activity [99].

3.9. Spathodea campanulata Buch.-Ham. ex DC. Spathodea campanulata (S. campanulata) is also from the Bignoniaceae family. It is a perennial shrub that grows in the subtropical and tropical areas in Africa. The whole plant (leaves, roots, stems, bark, and flowers) are used in folklore medicine as remedies for painful inflammations, stomach aches, diarrhea, kidney diseases, and urethral inflammations and as a diuretic [112]. The phytochemical constituents present in S. campanulata include saponins, tannins, anthraquinones, glycosides, phenols, carbohydrates, flavonoids, sterols, and triterpenoids [113, 114]. Pharmacological studies have revealed that the plant possesses analgesic, anti-inflammatory, antiplasmodial, anti-HIV, and antimalarial properties [114-117].

The antiulcer function in vivo of the ethanolic extract of S. campanulata was investigated against aspirin-induced gastric ulcer models in rats at doses of $200 \mathrm{mg} / \mathrm{kg}$ and $400 \mathrm{mg} / \mathrm{kg}$, with results showing substantial decreases in gastric volume, ulcer index, and free acidity [118]. This may be due to the phytochemical constituents present in the plant. Alcoholic and aqueous stem bark extracts of Spathodea campanulata have been reported by Radika as possessing antiulcer activity when tested in pylorus ligation, forced swim stress-induced, 
and indomethacin antiulcer models in Wistar albino rats [119]. The results demonstrated a markedly reduced ulceration in all three models. An increase in defensive factors like mucin and a decrease in aggressive factors like pepsin and $\mathrm{pH}$ were observed with testing involving the alcoholic extract. The presence of phytochemical constituents like flavonoids can avoid lipid peroxidation and prevent the degradation of gastric tissues by reactive oxygen reactive organisms [119].

\subsection{Mangifera indica L. Mangifera indica (M. indica) from} the Anacardiaceae family is an evergreen tree generally growing in tropical and savanna areas reaching a height of between 10 and $45 \mathrm{~m}$. Ethnomedicinal uses of some parts (leaves, bark, roots, fruits, and flowers) of the plant have been reported in the treatment of disorders including cough, hemorrhages, wounds, diarrhoea, ulcers, anorexia, dyspepsia, chronic dysentery, anemia, piles, kidney stones, tuberculosis, intestinal disorders, blood purification, nasal bleeding, and sunstroke $[120,121]$. The reported phytochemical constituents include vitamins, carotenoids, polyphenols, sterols, amino acids, flavonoids, and terpenes [122]. The reported pharmacological properties include antidiarrheal, gastroprotective, antioxidant, antidiabetic, hypolipidemic, anticancer, antiparasitic, antifungal, anti-HIV, antibacterial, and antispasmodic properties [120, 123, 124].

Ethanol and petroleum ether extracts obtained from Mangifera indica were investigated in vivo using an aspirininduced ulcer animal model. The results showed an effective reduction in the ulcer index [125], which could be attributed to the release of prostaglandins due to enhanced synthesis through the cyclooxygenase pathway in addition to ensuring bicarbonate and mucus secretion and decreased production of reactive oxygen species. It has been reported that Mangifera indica provides gastroprotection against gastric ulcers due to its cytoprotective, antioxidative, and antisecretory effects [126]. The ulcer index was substantially reduced compared to the standard drug ranitidine when the leaf extract was examined in rats with the pylorus ligation ulcer model. It can be inferred that the gastroprotective effect for the tested Mangifera indica extracts may be due to the synergistic effect of all secondary metabolites available in the leaves of the plant [127]. The ethanolic extract's antiulcer function obtained from the $M$. indica kernel evaluated by Prabhu using the pylorus ligation antiulcer model has demonstrated a marked reduction in ulceration [128]. Antiulcer tests involving the decoction of $M$. indica showed a marked reduction in gastric injury from $89.0 \pm 6.71$ (control group) to $9.25 \pm 2.75,4.50 \pm 3.30$, and 0 , respectively, in the ethanolinduced ulcer model, when decoction was administered orally at doses of 250, 500, and $1000 \mathrm{mg} / \mathrm{kg}$ in rats. Also, pretreatment of mice with the decoction by stress-induced and $\mathrm{HCl} /$ ethanol gastric ulcer models exhibited a significant reduction in the ulcer index [129]. This could be a result of the prevention of ethanol penetration through the gastric membrane, reduction in acid secretion, and prevention of the generation of reactive oxygen species. Enhanced bicarbonates and mucus production may also lead to the antiulcer effects of $M$. indica.
3.11. Paullinia pinnata Linn. Paullinia pinnata ( $P$. pinnata) from the family Sapindaceae is a climbing plant with woody stiff stems which normally grows in subtropical and tropical areas of Africa. Traditionally, all parts of the plant (leaves, roots, stems, and flowers) are used as a medicine for the treatment of typhoid fever, erectile dysfunction, malaria, dysentery, syphilis, eye disorders, abdominal pains, diarrhoea, wounds, gonorrhea, and waist pains [130-132]. The reported phytochemical constituents in Paullinia pinnata include flavonoids, alkaloids, cardiac glycosides, saponins, tannins, carbohydrates, sterols, triterpenoids, and steroidal glycosides [133-135]. The reported pharmacological studies include antiparasitic, antispasmodic, antimalarial, anti-inflammatory, and antimicrobial activities [132, 135, 136]. Antiulcer activity on Paullinia pinnata is scarce; however, the plant has been reported to treat stomach ache, wounds, and sores. For instance, $P$. pinnata extract ointment was investigated in in vitro and in vivo models of male Sprague-Dawley rats against incision and excision wound models in rats where $P$. pinnata ointment was administered. The results observed was a decrease in the epithelialization period by $47.6 \%$ with a marked decrease in the scar area by $48.3 \%$ compared to control. The significant wound healing action comparable to nitrofurazone (conventional wound healing remedy) proved that the methanolic extract of $P$. pinnata ointment supports wound healing [137]. Hence, the antiulcer activity of $P$. pinnata could be attributed to its free radical scavenging and antioxidant properties as well as phytochemicals such as alkaloids and tannins [131, 138].

3.12. Strophanthus hispidus DC. Strophanthus hispidus (S. hispidus) from the family Apocynaceae is a perennial shrub that generally grows in Africa. Several studies suggest that the entire plant (stem bark, leaves, and roots) has numerous therapeutic applications including the treatment of skin diseases, gonorrhea, dysentery, leprosy, diabetes, oedema, malaria, ulcers, rheumatism, and urine retention [139, 140]. The plant contains tannins, glycosides, saponins, flavonoids, alkaloids, resins, and rhamnose sugar [141]. The pharmacological properties investigated on Strophanthus hispidus include hypoglycemic, anti-inflammatory, antioxidant, and antimicrobial activities [142-144]. Ishola et al. reported antiulcer activity on the ethanolic extract obtained from the root of $S$. hispidus investigated in albino rats in three ulcer models, namely, ethanol, $\mathrm{HCl}$, and pylorus ligation [145]. Results from the ethanol-induced ulcer model indicated a marked reduction in ulceration compared to misoprostol, a standard drug. S. hispidus probably exhibits cytoprotective properties as a result of the release of free radical scavengers. Pharmacological reports show that the plant possesses antioxidant and antisecretory activities. Results from the $\mathrm{HCl}$-induced ulcer model indicated a marked reduction in ulceration comparable to cimetidine, a standard drug. Moreover, in the pyloric ligation-induced ulcer model, S. hispidus extract showed an effective reduction in gastric ulcers compared to omeprazole. Reduced ligation of gastric acid and its accumulation in the stomach of the albino rats were also observed. This explains that the S. hispidus extract has significant antiulcer properties in various animal models [145]. 
TABLE 1: Reported phytochemical constituents isolated from the list of ethnomedicinal plants with folkloric use for peptic ulcer disease.

\begin{tabular}{|c|c|c|c|c|}
\hline Plant name & Family & Part used & Phytochemical constituents & References \\
\hline $\begin{array}{l}\text { (1) Chromolaena odorata } \\
\text { (C. odorata) }\end{array}$ & Asteraceae & Leaves & $\begin{array}{l}\text { Alkaloids, flavonoids, tannins, steroids, } \\
\text { terpenoids, and cardiac glycosides }\end{array}$ & [24-27]. \\
\hline $\begin{array}{l}\text { (2) Alchornea cordifolia } \\
\text { (A. cordifolia) }\end{array}$ & Euphorbiaceae & Leaves & $\begin{array}{l}\text { Tannins, terpenoids, glycosides, alkaloids, } \\
\text { saponins, and flavonoids }\end{array}$ & {$[43]$. } \\
\hline $\begin{array}{l}\text { (3) Blighia sapida } \\
\text { (B. sapida) }\end{array}$ & Sapindaceae & Leaves/stem bark & $\begin{array}{l}\text { Cardiac glycosides, saponins, anthraquinones, } \\
\text { flavonoids, alkaloids, phlobatannins, and terpenes }\end{array}$ & {$[54]$} \\
\hline $\begin{array}{l}\text { (4) Cyperus rotundus } \\
\text { (C. rotundus) }\end{array}$ & Cyperaceae & Whole plant & $\begin{array}{c}\text { Tannins, alkaloids, triterpenoids, } \\
\text { flavonoids, phenolics, saponins, proteins, } \\
\text { essential oils, starch, carbohydrates, and } \\
\text { cardiac glycosides }\end{array}$ & {$[58,59]$} \\
\hline $\begin{array}{l}\text { (5) Azadirachta indica } \\
\text { (A. indica) }\end{array}$ & Meliaceae & Leaves & Alkaloids, saponins, tannins, and flavonoids & {$[67]$} \\
\hline $\begin{array}{l}\text { (6) Calotropis procera } \\
\text { (C. procera) }\end{array}$ & Apocynaceae & Leaves & $\begin{array}{c}\text { Flavonoids, polyphenolic compounds, stigmasterol, } \\
\beta \text {-sitosterol, alkaloids, saponins, and tannins }\end{array}$ & {$[77]$} \\
\hline $\begin{array}{l}\text { (7) Hoslundia opposita } \\
\text { (H. opposita) }\end{array}$ & Labiatae & Leaves and roots & $\begin{array}{c}\text { Alkaloids, tannins, flavonoids, phenols, } \\
\text { terpenoids, saponins, quinones in both } \\
\text { aqueous and ethanolic extracts }\end{array}$ & {$[91,92]$} \\
\hline $\begin{array}{l}\text { (8) Kigelia africana } \\
\text { (K. africana) }\end{array}$ & Bignoniaceae & Leaves & $\begin{array}{l}\text { Reducing sugars, saponins, flavonoids, } \\
\text { alkaloids, phytosterols, coumarin, } \\
\text { naphthoquinones, and glycosides }\end{array}$ & [101-104] \\
\hline $\begin{array}{l}\text { (9) Spathodea campanulata } \\
\text { (S. campanulata) }\end{array}$ & Bignoniaceae & Stem bark & $\begin{array}{l}\text { Saponins, tannins, anthraquinone } \\
\text { glycosides, phenols, carbohydrates, } \\
\text { flavonoids, sterols, and triterpenoids }\end{array}$ & {$[113,114]$} \\
\hline $\begin{array}{l}\text { (10) Mangifera indica } \\
\text { (M. indica) }\end{array}$ & Anacardiaceae & Leaves & $\begin{array}{l}\text { Vitamins, carotenoids, polyphenols, sterols, } \\
\text { amino acids, flavonoids, and terpenes }\end{array}$ & {$[122]$} \\
\hline $\begin{array}{l}\text { (11) Paullinia pinnata } \\
(P . \text { pinnata })\end{array}$ & Sapindaceae & All parts & $\begin{array}{l}\text { Flavonoids, alkaloids, cardiac glycosides, } \\
\text { saponins, tannins, carbohydrates, sterols, } \\
\text { triterpenoids, and steroidal glycosides }\end{array}$ & [133-135] \\
\hline $\begin{array}{l}\text { (12) Strophanthus hispidus } \\
\text { (S. hispidus) }\end{array}$ & Apocynaceae & Roots & $\begin{array}{l}\text { Tannins, glycosides, saponins, flavonoids, } \\
\text { alkaloids, resin, and rhamnose sugar }\end{array}$ & [141] \\
\hline $\begin{array}{l}\text { (13) Zingiber officinale } \\
\text { (ginger) }\end{array}$ & Zingiberaceae & Rhizome & $\begin{array}{l}\text { Alkaloids, steroids, terpenoids, flavonoids, } \\
\text { fats and oil, resins, and carbohydrates }\end{array}$ & {$[150]$} \\
\hline
\end{tabular}

Investigations conducted in the aspirin-induced ulcer model using an aqueous antiulcer drug formulated with $S$. hispidus as a constituent in albino rats demonstrated that the formulated drug markedly reduced ulceration compared to omeprazole, a standard drug. This could be because of the effective scavenging of free radicals' production due to the adequate antioxidant property of S. hispisdus. Also, reduced acid secretion and enhanced prostaglandin biosynthesis through the cyclooxygenase pathway ensured the bicarbonate and mucus secretion and decreased production of reactive oxygen species [146].

3.13. Zingiber officinale Rosc. Zingiber officinale (ginger) is a perennial horizontal rhizome from the family Zingiberaceae. It grows up to 1.5 to 3 feet tall. Ginger is native to India but now grows well in several African countries including Ghana. Zingiber officinale is used in traditional medicine as remedies for pain, rheumatism, diarrhoea, bronchitis, nausea, influenza, vomiting, asthma, hemorrhoids, bloated stomach, anemic conditions, chronic osteoarthritis, and diabetes [147149]. Phytochemical constituents found in Zingiber officinale include alkaloids, steroids, terpenoids, flavonoids, fats and oil, resins, and carbohydrates [150].

Zingiber officinale has been found to possess antimicrobial, antibacterial, antidiabetic, antiemetic, antifungal, anthelmintic, anti-inflammatory, antithrombotic, antiviral, antitumor, antitussive, antiulcer, and antioxidant properties [151, 152].

The antiulcer activity on the ethanolic extract of Zingiber officinale was investigated in adult Wistar rats by the use of the indomethacin-induced ulcer model. The result showed that the ethanolic extract of ginger at doses of 100, 200, and $400 \mathrm{mg} / \mathrm{kg}$ exhibited a decrease in gastric wounds in rats with an ulcer inhibition of $71.56 \%, 48.53 \%$, and $53.40 \%$, respectively, when compared to $100 \mathrm{mg} / \mathrm{kg}$ body weight of the standard drug, ranitidine, which has an ulcer inhibition of $78.40 \%$. The reduction in the gastric ulcer induced by indomethacin in the Wistar rats could be attributed to the increased production of prostaglandins in the cyclooxygenase pathway, ensuring bicarbonate and mucus secretion, decreased reactive oxygen species production, and inhibition of pepsin and acid secretion [153]. Zaman et al. also reported antiulcer actions in indomethacin-induced gastric lesions in 
TABLE 2: Reported pharmacological peptic ulcer studies (ulcer models and clinical studies) done on the list of ethnomedicinal plants with folkloric use for peptic ulcer disease.

\begin{tabular}{|c|c|c|c|c|}
\hline Plant Name & Family & Part used & Pharmacological studies & References \\
\hline $\begin{array}{l}\text { (1) Chromolaena } \\
\text { odorata (C. odorata) }\end{array}$ & Asteraceae & Leaves & Ethanol-induced ulcer model & {$[30,31]$} \\
\hline $\begin{array}{l}\text { (2) Alchornea } \\
\text { cordifolia (A. cordifolia) }\end{array}$ & Euphorbiaceae & Leaves & $\begin{array}{l}\text { Pylorus ligation, } \mathrm{HCI} / \text { ethanol-induced, } \\
\text { indomethacin, ethanol, and histamine } \\
\text { ulcer models }\end{array}$ & {$[44-46]$} \\
\hline $\begin{array}{l}\text { (3) Blighia } \\
\text { sapida (B. sapida) }\end{array}$ & Sapindaceae & Leaves & $\begin{array}{l}\text { HCl-ethanol, ethanol, cold-restraint } \\
\text { stress, indomethacin, and pylorus } \\
\text { ligation ulcer models }\end{array}$ & {$[55]$} \\
\hline $\begin{array}{l}\text { (4) Cyperus rotundus } \\
\text { (C. rotundus) }\end{array}$ & Cyperaceae & Whole plant & $\begin{array}{l}\text { Pylorus ligation, aspirin, and } \\
\text { histamine-induced gastric ulcer models }\end{array}$ & {$[62-64]$} \\
\hline $\begin{array}{l}\text { (5) Azadirachta } \\
\text { indica (A. indica) }\end{array}$ & Meliaceae & Leaves & $\begin{array}{l}\text { Pylorus ligation, cold-restraint stress, } \\
\text { ethanol, indomethacin, aspirin, and } \\
\text { acetic acid-induced ulcer models } \\
\text { In patients, the bark extract of } \\
\text { A. indica has therapeutic potential for the } \\
\text { management of gastro/duodenal ulcers }\end{array}$ & {$[10,70,71,74,75]$} \\
\hline $\begin{array}{l}\text { (6) Calotropis } \\
\text { procera (C. procera) }\end{array}$ & Apocynaceae & Leaves & $\begin{array}{l}\text { Aspirin, ethanol, indomethacin, pylorus } \\
\text { ligation, and aspirin-induced ulcer models }\end{array}$ & {$[83,84,86]$} \\
\hline $\begin{array}{l}\text { (7) Hoslundia opposita } \\
\text { (H. opposita) }\end{array}$ & Labiatae & Leaves and roots & $\begin{array}{c}\text { H. opposita aqueous extract against } \\
\text { Helicobacter pylori was demonstrated in } \\
\text { AGS human stomach cells }\end{array}$ & {$[95]$} \\
\hline $\begin{array}{l}\text { (8) Kigelia africana } \\
\text { (K. africana) }\end{array}$ & Bignoniaceae & Leaves & $\begin{array}{c}\text { Aspirin, histamine, and ethanol-induced } \\
\text { ulcer models }\end{array}$ & {$[102,107-110]$} \\
\hline $\begin{array}{l}\text { (9) Spathodea campanulata } \\
\text { (S. campanulata) }\end{array}$ & Bignoniaceae & Stem bark & $\begin{array}{l}\text { Aspirin, pylorus ligation, forced swim stress, } \\
\text { and indomethacin-induced ulcer models }\end{array}$ & {$[118,119]$} \\
\hline $\begin{array}{l}\text { (10) Mangifera } \\
\text { indica (M. indica) }\end{array}$ & Anacardiaceae & Leaves & $\begin{array}{l}\text { Aspirin, pylorus ligation, ethanol, stress, } \\
\text { and } \mathrm{HCl} / \text { ethanol ulcer-induced models }\end{array}$ & {$[125,127-129]$} \\
\hline $\begin{array}{l}\text { (11) Paullinia } \\
\text { pinnata (P. pinnata) }\end{array}$ & sapindaceae & All parts & & \\
\hline $\begin{array}{l}\text { (12) Strophanthus } \\
\text { hispidus (S. hispidus) }\end{array}$ & Apocynaceae & Roots & $\begin{array}{l}\text { Ethanol, } \mathrm{HCl} \text {, pylorus ligation, and } \\
\text { aspirin-induced ulcer models }\end{array}$ & {$[145,146]$} \\
\hline $\begin{array}{l}\text { (13) Zingiber } \\
\text { officinale (ginger) }\end{array}$ & Zingiberaceae & Rhizome & Indomethacin-induced ulcer models & {$[153,154]$} \\
\hline
\end{tabular}

rats with the aqueous extract of Zingiber officinale [154]. The result exhibited a marked decrease in gastric ulcer at dosage quantities of $200 \mathrm{mg} \mathrm{kg}^{-1}$ and $400 \mathrm{mg} \mathrm{kg}^{-1}$ when compared with omeprazole at a dosage quantity of $10 \mathrm{mg} / \mathrm{kg}$. Also, relative gastric ulcer inhibition of $40.91 \%$ and $57.58 \%$ compared to that of omeprazole which was $65.91 \%$ was obtained. This confirms that the aqueous Zingiber officinale extract exhibits antiulcer activity in the indomethacin-induced ulcer model investigated [154]. The aqueous Zingiber officinale extract was again evaluated in albino rats using the ulcer model by indomethacin. The result indicated that administration of the aqueous extract of Zingiber officinale orally at a regimen of $0.8 \mathrm{mg} / \mathrm{kg}$ body weight for a total of 14 days demonstrated a significant reduction in ulcer index comparable to omeprazole, a standard drug [155]. It could be due to the enhancement of the mucosal barrier and prevention of excessive acid secretion, increase in endogenous prostaglandin biosynthesis, and enhancement in mucus and bicarbonate production [156].
In another investigation, the antiulcer activity of the steamed extract of ginger was investigated in rats using the ethanol and $\mathrm{HCl}$-induced gastric ulcer models. The steamed extract of Zingiber officinale was administered orally for 14 days to rats before administration of ethanol and HCI to induce gastric injury in the experimental animal. The result showed that the pretreatment prevented gastric damage and enhanced the production of mucosal total nitrite/nitrate in gastric tissues. The findings concluded that steamed ginger extract may exhibit antiulcer activity in a rat model by reducing acute gastric ulcers. The preventive mechanism probably comes as a result of an increase in mucosal prostaglandin E2 synthesis and gastric antioxidation capability [157].

\section{Discussion}

Generally, peptic ulcer disease affects $5-10 \%$ of people globally [1]. Currently, due to the changes in our diet and because of emotional and social factors, there is a rise in this disease. 
A lot of orthodox medications have been manufactured for the management and or treatment of this disorder. Most of these medications are expensive and have side effects when taken. Herbal medications have been used in treating several diseases from times past before the discovery of most orthodox medicines. As a result, herbal medicines have been considered as having healthier cultural acceptability and having less harmful and less antagonistic effects [4]. Consequently, herbal medicines have become very attractive sources of new drugs and have demonstrated promising results in the treatment of various diseases including peptic ulcers. Several plants have been known to have folkloric use in the treatment of peptic ulcer disease, but not much is known about them.

In this review, thirteen plants, namely, Chromolaena odorata, Blighia sapida, Cyperus rotundus, Magnifera indica, Azadirachta indica, Alchornea cordifolia, Calotropis procera, Hoslundia opposita, Kigelia africana, Spathodea campanulata, Zingiber officinale, and Paullinia pinnata were assessed for their phytochemical constituents and pharmacological studies.

From this study, two of the plants under review, namely, Kigelia africana and Spathodea campanulata belong to the family Bignoniaceae. Further studies could be done to assess the antiulcer activity of other plants belonging to this plant family since these two might not be the only ones. Also, the two plants have some similar chemical constituents including flavonoids, saponins, sterols, glycosides, and quinones. Flavonoids and saponins, for instance, have been proven to have antiulcer activities [158]. Antiulcer studies could be carried out for plants that possess these two chemical constituents to ascertain the possibility of this suspected effect.

As shown in Table 1, several phytochemical constituents have been isolated from the enlisted plants but these are not exhaustive. Additional phytochemical analysis could be performed to source more of these constituents since plants are known to be rich in several components.

All the plants under review except Paullinia pinnata have undergone some form of pharmacological studies to confirm their use in peptic ulcer disease (Table 2). For Hoslundia opposita, a study has shown its effect on Helicobacter pylori but not on any animal ulcer model. Furthermore, among the listed plants in this review, Azadirachta indica is the only plant that has undergone patient studies as well as pharmacological animal ulcer model studies. Besides, the antiulcer activity in $C$. odorata has been verified; however, results from a toxicity analysis carried out on a rat model suggested that unregulated use of this plant extract may have negative effects on kidney function and intestinal histology [32]. Hence, doses for formulations must be carefully selected with accompanying toxicological evaluations of finished products containing $C$. odorata extracts. Further studies could be done to fill the above-listed gaps, namely, to employ other animal ulcer models which were not used for each plant to assess its activity, to employ human studies for all plants, and lastly to ascertain the ulcer preventive or treatment effect of Paullinia pinnata.

\section{Conclusion}

The review has successfully established certain potential plants available in Ghana which, in addition to having other pharmacological properties, have substantial antiulcer activity in animal models and certain clinical settings. These medicinal plants could be used individually or in combination for the formulation of herbal medicines for remedies of peptic ulcer disease in Ghana.

\section{Conflicts of Interest}

The authors declare that no conflict of interest exists for the publication of this article.

\section{Acknowledgments}

Support for this publication was given by CPMR/authors.

\section{References}

[1] M. E. Lauret, M. Rodriguez-Pelaez, P. Ivett, and R. Luis, "Peptic ulcer disease," Journal of Gastroenterology and Hepatobiliary Disorders, vol. 1, no. 1, p. 105, 2015.

[2] K. S. de Lira Mota, D. E. N. Dias, M. E. F. Pinto et al., "Flavonoids with gastroprotective activity," Molecules, vol. 14, no. 3, pp. 979-1012, 2009.

[3] J. L. Wallace and K. A. Sharkey, "Pharmacotherapy of gastric acidity, peptic ulcers, and gastroesophageal reflux disease," in Goodman and Gilman's The Pharmacological Basis of Therapeutics, L. L. Brunton, Ed., pp. 1307-1351, McGraw-Hill, New York, 2012.

[4] M. M. Pandey, S. Rastogi, and A. K. Rawat, "Indian herbal drug for general healthcare: an overview," The internet journal of alternative medicine, vol. 6, no. 1, pp. 1-10, 2008.

[5] T. S. Lakshmi, S. M. Lakshmi, S. S. Neelufar, G. R. Koteswara, and G. R. Prasanna, "Medicinal plants as anti-ulcer agents," Journal of Pharmacognosy and Phytochemistry, vol. 2, no. 4, pp. 91-97, 2013.

[6] D. Kaur, A. C. Rana, N. N. Sharma, and S. S. Kumar, "Herbal drugs with anti-ulcer activity," Journal of Applied Pharmaceutical Science, vol. 2, no. 3, pp. 160-165, 2012.

[7] S. Al-Radahe, K. A. Ahmed, S. Salama et al., "Anti-ulcer activity of Swietenia mahagoni leaf extract in ethanol-induced gastric mucosal damage in rats," Journal of Medicinal Plants Research, vol. 6, no. 12, pp. 988-997, 2012.

[8] Z. A. Zakaria, E. E. Abdul Hisam, C. M. Norhafizah et al., "Methanol extract of Bauhinia purpurea leaf possesses antiulcer activity," Medical Principles and Practice, vol. 21, no. 5, pp. 476-482, 2012.

[9] Z. Zabidi, W. N. Wan Zainulddin, S. S. Mamat et al., "Antiulcer activity of methanol extract of Melastoma malabathricum leaves in rats," Medical Principles and Practice, vol. 21, no. 5, pp. 501-503, 2012.

[10] P. S. Bhajoni, G. G. Meshram, and M. Lahkar, "Evaluation of the antiulcer activity of the leaves of Azadirachta indica: an experimental study," Integrative Medicine International, vol. 3, no. 1-2, pp. 10-16, 2016.

[11] S. A. Brito, C. L. F. de Almeida, T. I. de Santana et al., "Antiulcer activity and potential mechanism of action of the leaves of Spondias mombin L," Oxidative Medicine and Cellular Longevity, vol. 2018, Article ID 1731, 20 pages, 2018.

[12] S. Alqasoumi, M. al-Sohaibani, T. AlHowiriny, M. AlYahya, and S. R. Rafatullah, "Rocket Eruca sativa: A salad herb with 
potential gastric antiulcer activity," World Journal of Gastroenterology, vol. 15, no. 16, pp. 1958-1965, 2009.

[13] M. Abebaw, B. Mishra, and D. A. Gelayee, "Evaluation of anti-ulcer activity of the leaf extract of Osyris quadripartita Decne. Santalaceae in rats," Journal of Experimental Pharmacology, vol. Volume 9, pp. 1-11, 2017.

[14] R. E. McFadyen, "Chromolaena in East Timor: history, extent, and control," Chromolaena in the Asia-Pacific Region. Proceedings of the 6th International Workshop on Biological Control and Management of Chromolaena odorata. ACIAR Technical Reports 55, M. D. Day and M. F. RE, Eds., , pp. 810, ACIAR, Canberra, Australia, 2004.

[15] R. M. King and H. Robinson, "Chromolaena odorata Linnaeus," Phytologia, vol. 21, p. 544, 1970.

[16] J. M. Bissangou and J. M. Ouamba, "Valorisation chimique de quelques espèces aromatiques et médicinales du congo Ageratum conyzoïdes L, Chromolaena odorata King et Robinson, Hyptis suaveolens Poit et Lippia multitlora Moldenke," Pharmacopée et Médecine Traditionnelle Africaine, vol. 9, pp. 70-84, 1997.

[17] T. Odugbemi, Outlines and Pictures of Medicinal Plants from Nigeria, University of Lagos Press, Lagos, Nigeria, 2006.

[18] A. C. Akinmoladun and O. Akinloye, "Effect of Chromolaena odorata on hypercholesterolemia-related metabolic imbalances," in Proceedings of the Akure-Humboldt Kellogg/3rd SAAT Annual Conference on Medicinal Plants, pp. 287-290, Akure, Nigeria, 2007.

[19] R. D. G. Elion Itou, A. W. Etou Ossibi, C. Epa et al., "Antiinflammatory and analgesic effects of leaves of Chromolaena odorata L. King and Robinson," African Journal of Pharmacy and Pharmacology, vol. 11, no. 17, pp. 217-223, 2017.

[20] H. Pandith, X. Zhang, S. Thongpraditchote, Y. Wongkrajang, W. Gritsanapan, and S. J. Baek, "Effect of Siam weed extract and its bioactive component scutellarein tetramethyl ether on anti-inflammatory activity through NF- $\kappa \mathrm{B}$ pathway," Journal of Ethnopharmacology, vol. 147, no. 2, pp. 434-441, 2013.

[21] A. Agban, A. G. Koffi, K. A. Eyana, T. Kokou, B. Komlan, and K. Kossi, "Evaluation des activités antimicrobiennes de Tridax procumbens Asteraceae, Jatropha multifida Euphorbiaceae et de Chromolaena odorata Asteraceae," European Scientific Journal, vol. 9, no. 36, pp. 287-290, 2013.

[22] V. Kavitha, A. S. Mohamed, and R. Maruthi, "Studies on phytochemical screening and antioxidant activity of Chromolaena odorata and Annona squamosa," International Journal of Innovative Research in Science, Engineering and Technology, vol. 2, no. 12, pp. 7317-7321, 2013.

[23] K. K. Naidoo, R. M. Coopoosamy, and G. Naidoo, "Screening of Chromolaeana odorata L. King and Robinson for antibacterial and antifungal properties," Journal of Medicinal Plant Research, vol. 5, no. 19, pp. 4859-4862, 2011.

[24] M. Onkaramurthy, V. P. Veerapur, B. S. Thippeswamy, T. N. Madhusudana Reddy, H. Rayappa, and S. Badami, "Anti-diabetic and anti-cataract effects of Chromolaena odorata Linn., in streptozotocin-induced diabetic rats," Journal of Ethnopharmacology, vol. 145, no. 1, pp. 363-372, 2013.

[25] J. A. M. de Oliveira, D. I. Bernardi, R. B. Balbinot et al., "Chemotaxonomic value of flavonoids in _Chromolaena congesta_ (Asteraceae)," Biochemical Systematics and Ecology, vol. 70, pp. 7-13, 2017.

[26] D. A. Putri and S. Fatmawati, "A new flavanone as a potent antioxidant isolated from Chromolaena odorata L. leaves,"
Evidence-Based Complementary and Alternative Medicine, vol. 2019, 12 pages, 2019.

[27] A. C. Akinmoladun, E. O. Ibukun, and I. A. Dan-Ologe, "Phytochemical constituents and antioxidant properties of extracts from the leaves of Chromolaena odorata," Scientific Research and Essay, vol. 2, pp. 191-194, 2007.

[28] K. Panyaphu, T. van On, P. Sirisa-ard, P. Srisa-nga, S. ChansaKaow, and S. Nathakarnkitkul, "Medicinal plants of the Mien (Yao) in Northern Thailand and their potential value in the primary healthcare of postpartum women," Journal of Ethnopharmacology, vol. 135, no. 2, pp. 226-237, 2011.

[29] A. A. Mahmood, M. H. Nur Jannah, K. Sidik, and I. Salmah, "Cytoprotective effects of honey in combination with aqueous and ETHANOLEXTRACTS from Chromolaena odorata L. (Eupatorium odoratum L.) in rats," Journal of Health and Translational Medicine, vol. 9, no. 1, pp. 7-13, 2006.

[30] C. Agbor, "Gastroprotective effect of the combined aqueous extract of Ocimum gratissimum and Chromolaena odorata on experimentally induced peptic ulcer in Wistar rats," Ejpmr, vol. 6, no. 8, pp. 44-48, 2019.

[31] T. S. Paul, B. B. Das, B. Ingale, N. Killedar, and K. G. Apte, "Oral intake of polyphenols of Chromolaena odorata: a perspective in peptic ulcer, thrombocytopenia, and heparininduced bleeding diathesis in rodent model," Pharmacognosy Research, vol. 10, no. 4, pp. 426-431, 2018.

[32] S. Anyanwu, I. J. Inyang, E. A. Asemota, O. O. Obioma, D. C. Okpokam, and V. O. Agu, "Effect of ethanolic extract of _Chromolaena odorata_ on the kidneys and intestines of healthy albino rats," Integrative Medicine Research, vol. 6, no. 3, pp. 292-299, 2017.

[33] K. O. Timibitei, P. C. Alikwe, S. N. Wekhe, and E. I. Ohimain, "Effects of Alchornea cordifolia root bark, seeds and pod husks on the growth response and visceral organs of rabbits," Nigerian Journal of Agriculture, Food and Environment, vol. 9, pp. 23-27, 2013.

[34] G. A. Agbor, T. Léopold, and N. Y. Jeanne, "The antidiarrhoeal activity of Alchornea cordifolia leaf extract," Phytotherapy Research, vol. 18, no. 11, pp. 873-876, 2004.

[35] B. M. Amos-Tautua, S. S. Angaye, and G. Jonathan, "Phytochemical screening and antimicrobial activity of the methanol and chloroform extracts of Alchornea cordifolia," Journal of Emerging Trends in Engineering and Applied Sciences, vol. 2, no. 3, pp. 445-447, 2011.

[36] D. Gatsing, C. F N Nkeug, B. F NjiNka, J. R. Kuiate, and F. M Tchouan, "Antibacterial activity, bioavailability and acute toxicity evaluation of the leaf extract of Alchornea cordifolia (Euphorbiaceae)," International Journal of Pharmacology, vol. 6, no. 3, pp. 173-182, 2010.

[37] C. Agyare, A. Ansah, P. Ossei, J. Apenteng, and Y. Boakye, "Wound healing and anti-infective properties of Myrianthus arboreus and Alchornea cordifolia," Medicinal Chemistry, vol. 4, no. 7, pp. 533-539, 2014.

[38] G. K. Mesia, G. L. Tona, T. H. Nanga et al., “Antiprotozoal and cytotoxic screening of 45 plant extracts from Democratic Republic of Congo," Journal of Ethnopharmacology, vol. 115, no. 3, pp. 409-415, 2008.

[39] R. K. Mohammed, S. Ibrahim, S. E. Atawodi, E. D. Eze, and J. B. Suleiman, "Anti-diabetic and haematological effects of n-butanol fraction of Alchornea cordifolia leaf extract in streptozotocin-induced diabetic Wistar rats," Global Journal of Medicinal Plants Research, vol. 1, pp. 14-21, 2012. 
[40] H. M. Manga, D. Brkic, D. E. Marie, and J. Quetin-Leclercq, "In vivo anti-inflammatory activity of_Alchornea cordifolia_ (Schumach. \& Thonn.) Mull. Arg. (Euphorbiaceae)," Journal of Ethnopharmacology, vol. 92, no. 2-3, pp. 209-214, 2004.

[41] M. E. Ubulom Peace, F. Alozie Mfon, and A. Umoinyang, "Evaluation of in vivo antiplasmodial efficacy of ethanol leaf and root extracts of Alchornea cordifolia," World Journal of Pharmaceutical Research, vol. 17, no. 3, pp. 1296-1305, 2018.

[42] A. A. Jean-Baptiste, M. Pierre, N. J. Verdier, D. Aïssata, S. T. Béatrice, and D. D. Sébastien, "The assessment of Alchornea cordifolia activity in aflatoxicosis reduction in rat," Journal of Antioxidant Activity, vol. 1, no. 3, p. 1, 2017.

[43] N. M. Ngaha, I. Dahlan, and L. D. Massoma, "Alchornea cordifolia, a special plant for traditional medicine: a review," Journal of Agroecology and Natural Resource, vol. 3, no. 2, pp. 140-144, 2016.

[44] T. B. Nguelefack, P. Watcho, L. N. M. Sylvie, and A. Kamanyi, "Effects of the methanolic leaf extract of Alchornea cordifolia (Schum \& Thonn) Muell. Arg. on different gastric ulcer models in rat," Cameroon Journal of Experimental Biology, vol. 1, pp. 54-66, 2005.

[45] I. L. Osafanme, A. U. Mark-Maria, I. P. Adejoh, N. A. P. Chukwuemeka, and O. E. Okonkwo, "Anti-ulcerogenic activity of a polyherbal formulation (Exr-Hf) on experimental ulcer models," International Journal of Advanced Research, vol. 5, no. 10, pp. 147-156, 2018.

[46] A. Adeyemi, A. E. Omonigbehin, S. Stella, O. Oluwatosin, and S. Jumoke, "Antibacterial activity of extracts of Alchornea cordifolia (Schum and Thonn) Mull. Arg., Boerhavia diffusa (L) and Bridellia micranthaI (Hoscht) Baill. used in traditional medicine in Nigeria on Helicobacter pylori and four diarrhoeagenic bacterial pathogens," African Journal of Biotechnology, vol. 7, no. 20, pp. 3761-3764, 2008.

[47] G. O. Oyeleke, O. A. Oyetade, F. Afolabi, and B. M. Adegoke, "Nutrients, Antinutrients and Physicochemical Compositions of Blighia Sapida Pulp and Pulp Oil (Ackee Apple)," IOSR Journal of Applied Chemistry, vol. 4, no. 1, pp. 5-8, 2013.

[48] M. R. M. Ekué, B. Sinsin, O. Eyog-Matig, and R. Finkeldey, "Uses, traditional management, perception of variation and preferences in ackee (Blighia sapida K.D. Koenig) fruit traits in Benin: implications for domestication and conservation," Journal of Ethnobiology and Ethnomedicine, vol. 6, no. 1, pp. 12-14, 2010.

[49] D. Louppe, A. Asamoah, C. Antwi-Bosiako, K. FrimpongMensah, A. Atta-Boateng, and C. S. Montes, "Blighia sapida K.D.Koenig," in Prota Timbers/Boisd'oeuvre 2. [CD-Rom], R. H. M. J. Lemmens, D. Louppe, and A. A. Oteng-Amoako, Eds., vol. 7, PROTA, Wageningen, Netherlands, 2010.

[50] J. Morton, Akee. In: Fruits of Warm Climates, Julia F. Morton, Miami, FL, 1987.

[51] A. A. Gbolade, "Inventory of antidiabetic plants in selected districts of Lagos State, Nigeria," Journal of Ethnopharmacology, vol. 121, no. 1, pp. 135-139, 2009.

[52] O. A. Ojo, B. O. Ajiboye, O. D. Imiere, O. Adeyonu, I. Olayide, and A. Fadaka, "Antioxidative Properties of Blighia sapida K.D. Koenig Stem Bark Extract and Inhibitory Effects on Carbohydrate Hydrolyzing Enzymes Associated with Non-Insulin Dependent Diabetes Mellitus," Pharmacognosy Journal, vol. 10, no. 2, pp. 376-383, 2018.

[53] A. N. Saidu, A. Mann, and C. D. Onuegbu, "Phytochemical Screening and Hypoglycemic Effect of Aqueous Blighia sapida Root Bark Extract on Normoglycemic Albino Rats," British Journal of Pharmaceutical Research, vol. 2, no. 2, pp. 89-97, 2012.

[54] P. C. Ubulom Peace, E. Udobi Chinweizu, I. Akpabio Ekaete, and E. Udeme, "Antimicrobial Activities of Leaf and Stem Bark Extracts of Blighia sapida," Journal of Plant Studies, vol. 2, no. 2, 2013.

[55] I. A. Oreagba, I. O. Ishola, and B. O. Oremule, "Gastroprotective and antisecretory properties of the hydroethanolic leaf extract of Blighia sapida (Sapindaceae) in rats," International Journal of Medical and Dental Science Invention, vol. 1, no. 2, pp. 38-47, 2016.

[56] O. T. Adedosu, J. A. Badmus, G. E. Adeleke, E. O. Olagoke, and O. O. Babalola, "Effects of aqueous extract of Blighia sapida leaves on ethanol-induced gastric ulcer in male Wistar rats," Advances in Life Science and Technology, vol. 66, pp. 38-68, 2018.

[57] A. Senthilkumar and V. Venkatesalu, "Phytochemical analysis and antibacterial activity of essential oil of Clausena anisata (Wild). Hook. F. ex Benth," International Journal Integrative Biology, vol. 5, no. 2, pp. 116-120, 2009.

[58] A. R. Kasarkar, M. S. Thakur, S. S. Chougale et al., "Preliminary phytochemical investigation of the leaves of Cynodon Dactylon (L.) Pers., Cyperus rotundus L. and Typha Angustifolia L," Journal of Medicinal Plants Studies, vol. 5, no. 4, pp. 203-205, 2017.

[59] R. Jeyasheela, K. Chairman, C. Padmalatha, and A. J. A. Ranjit Singh, "Isolation and phytochemical characterization of bioactive compounds from the rhizomes of Cyperus rotundus," Global Journal of Science Frontier Research; C Biological Science, vol. 14, no. 2, pp. 1-8, 2014.

[60] N. Singh and B. R. Pandey, "Phyto-pharmacotherapeutics of Cyperus rotundus L," Indian Journal of Natural Products and Recourses, vol. 3, no. 4, pp. 467-476, 2012.

[61] B. Das, D. Pal, and A. A. Haldar, "Review on Cyperus rotundus as a tremendous source of pharmacologically active herbal medicine," International Journal of Green Pharmacy (IJGP), vol. 9, no. 4, pp. 198-203, 2015.

[62] M. Ahmad, M. Rookh, A. B. Rehman, N. Muhammad, M. Younus, and A. Wazir, "Assessment of anti-inflammatory, anti-ulcer and neuropharmacological activities of Cyperus rotundus Linn," Pakistan Journal of Pharmaceutical Sciences, Conference Issue, vol. 27, no. 6, pp. 22412246, 2014.

[63] R. Rajakrishnan, A. H. Alfarhan, A. M. Al-Ansari et al., "Therapeutic efficacy of the root tubers of Aconitum heterophyllum and its substitute Cyperus rotundus in the amelioration of pylorus ligation induced ulcerogenic and oxidative damage in rats," Saudi Journal of Biological Sciences, vol. 27, no. 4, pp. 1124-1129, 2020.

[64] A. Mohammad, B. H. Nagarajaiah, and B. L. Kudagi, "Experimental evaluation of antiulcer activity of Cyperus rotundus," Asian Journal of Biochemical and Pharmaceutical Research, vol. 2, pp. 261-268, 2012.

[65] J. Conrick, Neem-The Ultimate Herb Literature from Pure Gar Neem: A Tree for Solving Global Problems, National Academy Press, 2005.

[66] K. Biswas, I. Chattopadhyay, R. K. Banergee, and U. Bandyopadhyay, "Biological activities and medicinal properties of neem (Azadirachta indica)," Current Science, vol. 82, pp. 1336-1345, 2002. 
[67] R. Subapriya and S. Nagini, "Medicinal properties of neem leaves: a review," Current Medicinal Chemistry. Anti-Cancer Agents, vol. 5, no. 2, pp. 149-156, 2005.

[68] G. K. Prashanth and G. M. Krishnaiah, "Chemical composition of the leaves of Azadirachta indica Linn (neem)," Int $J$ Adv Eng Tech Manag Appl Sci, vol. 2004, no. 1, pp. 21-31, 2004.

[69] J. M. Scheiman, "NSAIDs, gastrointestinal injury, and cytoprotection," Gastroenterology Clinics of North America, vol. 25, no. 2, pp. 279-298, 1996.

[70] I. Chattopadhyay, B. Nandi, R. Chatterjee, K. Biswas, U. Bandyopadhyay, and R. K. Banerjee, "Mechanism of antiulcer effect of Neem (Azadirachta indica) leaf extract: effect on H+-K+-ATPase, oxidative damage and apoptosis," InflammoPharmacology, vol. 12, no. 2, pp. 153-176, 2004.

[71] S. Farzana, S. P. Saha, N. Sultana, and M. I. Khan, "Gastroprotective Effect of Azadirachta indica Leaves (Neem) Extract on Aspirin Induced Gastric Ulcer in Rats," Delta Medical College Journal, vol. 7, no. 2, pp. 61-66, 2020.

[72] G. Kauffman, "Aspirin-induced gastric mucosal injury: lessons learned from animal models," Gastroenterology, vol. 96, no. 2, pp. 606-614, 1989.

[73] G. P. Garg, S. K. Nigam, and C. W. Ogle, "The gastric antiulcer effects of the leaves of theNeemTree," Planta Medica, vol. 59, no. 3, pp. 215-217, 1993.

[74] Y. Raji, I. A. Ogunwande, C. A. Osadebe, and G. John, "Effects of_Azadirachta indica_extract on gastric ulceration and acid secretion in rats," Journal of Ethnopharmacology, vol. 90, no. 1, pp. 167-170, 2004.

[75] U. Bandyopadhyay, K. Biswas, A. Sengupta et al., "Clinical studies on the effect of Neem Azadirachta indica bark extract on gastric secretion and gastroduodenal ulcer," Life Sciences, vol. 75, no. 24, pp. 2867-2878, 2004.

[76] N. R. Pillai and G. Santhakumari, "Effects of nimbidin on acute and chronic Gastroduodenal ulcer models in experimental animals," Planta Medica, vol. 50, no. 2, pp. 143-146, 1984.

[77] S. R. Morcelle, N. O. Caffini, and N. Priolo, "Proteolytic properties of _Funastrum clausum_ latex," Fitoterapia, vol. 75, no. 5, pp. 480-493, 2004.

[78] M. S. Bairagi, P. Ghule, and R. Gilhotra, "Pharmacology of natural products: a recent approach on Calotropis gigantea and Calotropis procera," Ars Pharm, vol. 59, no. 1, pp. 3744, 2018.

[79] K. Kiritikar and B. Basu, "Indian medicinal plants," Int B Distrib, vol. 3, pp. 1432-1436, 1987.

[80] S. M. Bairagi, A. A. Aher, N. Nema, and I. B. Pathan, "Evaluation of Anti-Diarrhoeal Activity of the Leaves Extract of Ficus Microcarpa L. (Moraceae)," Marmara Pharmaceutical Journal, vol. 3, no. 18, pp. 135-135, 2014.

[81] V. L. Kumar and N. Basu, "Anti-inflammatory activity of the latex of _Calotropis procera_, Journal of Ethnopharmacology, vol. 44, no. 2, pp. 123-125, 1994.

[82] A. Basu and A. K. N. Chaudhuri, "Preliminary studies on the antiinflammatory and analgesic activities of _Calotropis procera_ root extract," Journal of Ethnopharmacology, vol. 31, no. 3, pp. 319-324, 1991.

[83] S. N. Tours and S. G. Talele, "Gastric antiulcer and antiinflammatory activities of Calotropis procera stem bark," Revista Brasileira de Farmacognosia, vol. 21, no. 6, pp. 1118-1126, 2011.
[84] S. Quazi, K. Mathur, and S. Arora, "Calotropis procera: an overview of its phytochemistry and pharmacology," Indian Journal Drugs, vol. 1, no. 1, pp. 63-69, 2013.

[85] M. Umamaheswari, K. Asokkumar, R. Rathidevi, A. T. Sivashanmugam, V. Subhadradevi, and T. K. Ravi, "Antiulcer and _in vitro_ antioxidant activities of _Jasminum grandiflorum_L.," Journal of Ethnopharmacology, vol. 110, no. 3, pp. 464-470, 2007.

[86] M. Khazaei and H. Salehi, "Protective effect of Falcaria vulgaris extract on ethanol-induced gastric ulcer in rat," Iranian Journal of Pharmacology and Therapeutics, vol. 5, no. 1, pp. 43-46, 2006.

[87] N. O. Muhammad, J. O. Akolade, L. A. Usman, and O. B. Oloyede, "Haematological parameters of alloxan-induced diabetic rats treated with leaf essential oil of Hoslundia opposita (Vahl.)," EXCLI Journal, vol. 11, no. 1, p. 671, 2012.

[88] I. Köhler, K. Jenett-Siems, C. Kraft et al., "Herbal Remedies Traditionally Used Against Malaria in Ghana: BioassayGuided Fractionation of Microglossa pyrifolia (Asteraceae)," Zeitschrift für Naturforschung C, vol. 57, no. 11-12, pp. 10221027, 2002.

[89] K. Annan and R. Dickson, "Evaluation of Wound Healing Actions of Hoslundia opposita Vahl, Anthocleista nobilis G. Don. and Balanites aegyptiaca L," Journal of Science and Technology (Ghana), vol. 28, no. 2, 2008.

[90] S. C. Chhabra, F. C. Uiso, and E. N. Mshiu, "Phytochemical screening of tanzanian medicinal plants. I," Journal of Ethnopharmacology, vol. 11, no. 2, pp. 157-179, 1984.

[91] A. A. Dantankwa, "Antibacterial activities of some Ghanaian medicinal plants against methicillin resistant Staphylococcus aureus (MRSA) and methicillin sensitive Staphylococcus aureus (MSSA)," A thesis submitted to the Department of Biochemistry and Biotechnology, College of Science, Kwame Nkrumah University Of Science And Technology, Kumasi, Ghana, 2016.

[92] O. O. Ojo, I. I. Anibijuwon, and O. O. Ojo, "Studies on extracts of three medicinal plants of South-Western Nigeria: Hoslundia opposita, Lantana camara, and Cymbopogon citratus," Advances in Natural and Applied Sciences, vol. 4, no. 1, pp. 93-98, 2010.

[93] O. A. Olajide, S. O. Awe, and J. M. Makinde, "Central nervous system depressant effect of Hoslundia opposita Vahl," Phytotherapy Research, vol. 13, no. 5, pp. 425-426, 1999.

[94] H. Achenbach, R. Waibel, M. H. H. Nkunya, and H. Weenen, "Antimalarial compounds from_Hoslundia opposita_," Phytochemistry, vol. 31, no. 11, pp. 3781-3784, 1992.

[95] G. A. Pesewu, R. R. Cutler, and D. P. Humber, "Antibacterial activity of plants used in traditional medicines of Ghana with particular reference to MRSA," Journal of Ethnopharmacology, vol. 116, no. 1, pp. 102-111, 2008.

[96] C. Agyare, A. Asase, M. Lechtenberg, M. Niehues, A. Deters, and A. Hensel, "An ethnopharmacological survey and _in vitro_ confirmation of ethnopharmacological use of medicinal plants used for wound healing in BosomtwiAtwima-Kwanwoma area, Ghana," Journal of Ethnopharmacology, vol. 125, no. 3, pp. 393-403, 2009.

[97] M. M. Iwu, Handbook of African Medicinal Plants, CRS Press, Florida, United States, 1993.

[98] B. V. Owoyele, S. O. Oguntoye, K. Dare, B. A. Ogunbiyi, E. A. Aruboula, and A. O. Soladoye, "Analgesic, anti-inflammatory, and antipyretic activities from flavonoid fraction from 
Chromolaena odorata," Journal of Medicinal Plants Research, vol. 2, no. 9, pp. 219-225, 2008.

[99] D. Santos, M. Matheus, M. T. Olaleye et al., "Antioxidant and antiulcer potential of aqueous leaf extract of Kigelia Africana against ethanol-induced ulcer in rats," Excli Journal, vol. 13, pp. 323-330, 2014.

[100] A. G. Olatunji and O. Ortolani, "Comprehensive scientific demystification of Kigelia africana: a review," African Journal of Pure and Applied Chemistry, vol. 3, no. 9, pp. 158-164, 2009.

[101] S. E. O. Atawodi and O. D. Olowoniyi, "Pharmacological and therapeutic activities of Kigelia africana (Lam.) Benth," Annual Research \& Review In Biology., vol. 5, no. 1, pp. 117, 2015.

[102] R. T. Orole, O. O. Orole, and T. O. Adejumo, “Antiulcerogenic Activity of Kigelia africana, Nauclea latifolia and Staudtia stipitata on Induce Ulcer in Albino Rats," European Journal of Medicinal Plantse, vol. 3, no. 4, pp. 577-590, 2013.

[103] O. J. Owolabi and E. K. I. Omogbai, "Analgesic and antiinflammatory activities of the ethanolic stem bark extract of Kigelia africana (Bignoniaceae)," African Journal of Biotechnology, vol. 6, no. 5, pp. 582-585, 2007.

[104] O. Atolani and A. G. Olatunji, "Epicuticular wax and volatiles of Kigelia pinnata leaf extract," Ethnobotanical leaflets, vol. 2010, no. 14, p. 797, 2010.

[105] O. M. Grace, M. E. Light, K. L. Lindsey, D. A. Mulholland, J. van Staden, and A. K. Jager, "Antibacterial activity and isolation of active compounds from fruit of the traditional African medicinal tree_Kigelia africana_,"South African Journal of Botany., vol. 68, no. 2, pp. 220-222, 2002.

[106] A. Nabatanzi, S. M. Nkadimeng, N. Lall, J. D. Kabasa, and L. J. McGaw, "Antioxidant and Anti-Inflammatory Activities of Kigelia africana (Lam.) Benth.," Evidence-Based Complementary and Alternative Medicine, vol. 2020, 11 pages, 2020.

[107] H. Anvesh, V. K. Varma, and S. Rajyalaxmi, "Antiulcer effect of the methanolic extract of Kigelia africana Lam, Benth (Bignoniaceae)," Pharmacologyonline, vol. 1, pp. 344-351, 2010.

[108] H. W. Davenport, "Fluid produced by gastric mucosa during damage by acetic and salicylic acid," Gastroenterology, vol. 50, no. 4, pp. 487-499, 1966.

[109] K. Hamamalini, S. Suvidha, B. Anurag, and V. Uma, "Evaluation of anti-ulcer activity of Kigelia africana, Sophora interrupta and Holoptelea integrifolia in rats," int. J. Res, Phytochem. Pharmacol, vol. 2, no. 2, pp. 84-89, 2012.

[110] B. Halliwell, Free Radicals in Biology and Medicine, Oxford University Press, Clarrando, 1985.

[111] A. Pianaro, J. P. Pinto, D. T. Ferreira, N. K. Ishikawa, and R. Braz-Filho, "Iridóide glicosilado e derivados fenólicos antifúngicos isolados das raízes de Spathodea campanulata," Semina: Ciências Agrárias, vol. 28, no. 2, pp. 251-256, 2009.

[112] E. E. Ilodigwe and A. P. Akah, "Spathodea campanulata: an experimental evaluation of the analgesic and antiinflammatory properties of a traditional remedy," Asian Journal of Medical Sciences, vol. 1, no. 2, pp. 35-38, 2009.

[113] G. Niyonzima, G. Laekeman, M. Witvrouw et al., "Hypoglycemic, anticomplement and anti-HIV activities of _Spathodea campanulata_stem bark," Phytomedicine, vol. 6, no. 1, pp. 45-49, 1999.

[114] E. H. Park, J. H. Kahng, S. H. Lee, and K. H. Shin, “An antiinflammatory principle from cactus," Fitoterapia, vol. 72, no. 3, pp. 288-290, 2001.
[115] J. M. Makinde, E. K. Adesogan, and O. O. G. Amusan, "The schizontocidal activity ofSpathodea campanulata leaf extract onPlasmodium berghei berghei in mice," Phytotherapy Research, vol. 1, no. 2, pp. 65-68, 1987.

[116] J. M. Makinde, O. O. G. Amusan, and E. K. Adesogan, “The Antimalarial Activity ofSpathodea campanulataStem Bark Extract onPlasmodium berghei bergheiin Mice," Planta Medica, vol. 54, no. 2, pp. 122-125, 1988.

[117] S. Khatri, R. B. Goswami, and S. Jain, "Phytochemical screening and evaluation of antiulcer activity of ethanolic extract of Spathodea campanulata leaves," Journal of Drug Delivery and Therapeutics, vol. 9, no. 4-s, pp. 1012-1015, 2019.

[118] D. S. Radika, Evaluation of aqueous and alcoholic stem bark of Spathodea campunulata for anti-ulcer activity, Dissertation submitted to the Rajiv Gandhi, University of Health Science, Bangalore, Karnataka, 2010.

[119] G. M. Masud Parvez, "Pharmacological activities of mango (Mangifera Indica): a review," Journal of Pharmacognosy and Phytochemistry, vol. 5, no. 3, pp. 1-7, 2016.

[120] M. S. Khandare, "Mangifera indica (Mangifera indica Linn). A medicinal and holy plant," Journal of Medicinal Plants Studies, vol. 4, no. 4, pp. 44-46, 2016.

[121] J. C. Barreto, M. T. S. Trevisan, W. E. Hull et al., "Characterization and Quantitation of Polyphenolic Compounds in Bark, Kernel, Leaves, and Peel of Mango (Mangifera indicaL.)," Journal of Agricultural and Food Chemistry, vol. 56, no. 14, pp. 5599-5610, 2008.

[122] G. D. Noratto, M. C. Bertoldi, K. Krenek, S. T. Talcott, P. C. Stringheta, and S. U. Mertens-Talcott, "Anticarcinogenic Effects of Polyphenolics from Mango (Mangifera indica) Varieties," Journal of Agricultural and Food Chemistry, vol. 58, no. 7, pp. 4104-4112, 2010.

[123] A. Bhowmik, L. A. Khan, M. Akhter, and B. Rokeya, "Studies on the antidiabetic effects of Mangifera indica stem-barks and leaves on nondiabetic type-1 and type-2 diabetic model rats," Bangladesh Journal of Pharmacology, vol. 4, no. 2, pp. 110114, 2009.

[124] N. Neelima, M. Sudhakar, M. B. Patil, and B. W. S. Lakshmi, "Antiulcer activity and HPTLC analysis of Mangifera indica L. leaves," International Journal of Pharmaceutical and Phytopharmacology Research, vol. 1, no. 4, pp. 146-155, 2012.

[125] A. Carvalho, M. Guedes, A. de Souza et al., "Gastroprotective Effect of Mangiferin, a Xanthonoid from Mangifera indica, against Gastric Injury Induced by Ethanol and Indomethacin in Rodents," Planta Medica, vol. 73, no. 13, pp. 1372-1376, 2007.

[126] R. M. S. Ashour, S. S. El-Hawary, S. H. El-Gayed, H. A. Gad, and G. A. Abdel Jaleel, "Genetic, chemical, and biological diversity in Mangifera indica L. cultivars," Pharmacognosy Research, vol. 12, no. 2, pp. 186-193, 2020.

[127] K. R. S. Prabhu, “Assessment of antiulcer activity of ethanolic extract of Mangifera indica seed kernel using acid ethanolinduced ulcer model," International Journal of Current Microbiology App. Science, vol. 4, no. 4, pp. 854-860, 2015.

[128] Z. P. Lima, J. A. Severi, C. H. Pellizzon et al., "Can the aqueous decoction of mango flowers be used as an antiulcer agent?," Journal of Ethnopharmacology, vol. 106, no. 1, pp. 29-37, 2006.

[129] M. G. Magaji, Y. Jamilu, M. Sani, and Y. Musa, "Evaluation of the anti-malarial activity of ethanolic leaves extract of Paullinia pinnata (Sapindaceae)," Nigerian Journal of Pharmaceutical Sciences, vol. 2007, no. 6, pp. 67-72, 2007. 
[130] D. Abbiw, Useful Plants of Ghana, Intermediate Technology Publication Ltd and the Royal Botanic Gardens, KEW, London, UK, 1990.

[131] P. Lunga, J. de Tamokou, S. P. C. Fodouop, J.-R. Kuiate, J. Tchoumboue, and D. Gatsing, "Antityphoid and radical scavenging properties of the methanol extracts and compounds from the aerial part of Paullinia pinnata," SpringerPlus, vol. 3, no. 1, p. 302, 2014.

[132] B. Hele, K. Metowogo, A. P. Mouzou et al., "Effect of the hydro-alcoholic leaves extract of Paullinia pinnata (Lin.) on rats skeletal muscle regeneration after contusion injury and phytochemical analysis," Journal of Pharmacognosy and Phytochemistry, vol. 6, no. 5, pp. 361-367, 2017.

[133] E. Dongo, H. Hussain, R. S. Miemanang, D. Tazoo, B. Schulz, and K. Krohn, "Chemical Constituents of Klainedoxa gabonenses and Paullinia pinnata," Records of Natural Products, vol. 3, no. 3, pp. 165-169, 2009.

[134] A. Zamble, M. Carpentier, A. Kandoussi et al., "Paullinia pinnata extracts rich in polyphenols promote vascular relaxation via endothelium-dependent mechanisms," Journal of Cardiovascular Pharmacology, vol. 47, no. 4, pp. 599-608, 2006.

[135] P. K. Lunga, X.-J. Qin, X. W. Yang, J.-R. Kuiate, Z. Z. Du, and D. Gatsing, "Antimicrobial steroidal saponin and oleananetype triterpenoid saponins from Paullinia pinnata," BMC Complementary and Alternative Medicine, vol. 14, no. 1, 2014.

[136] M. O. NAFIU, S. S. OLANIYI, M. O. SALAWU, A. A.-n. AJAO, and M. A. AKANJI, "Studies on Ameliorative Effects of Polyphenolic Extract from Paullinia pinnata L. (Sapindaceae) on Carbon Tetrachloride - Induced Hepatotoxicity and Oxidative Stress: an in vivo Assessment," Notulae Scientia Biologicae, vol. 10, no. 1, pp. 79-86, 2018.

[137] K. Annan, R. Govindarajan, and E. Kisseih, "Wound Healing and Cytoprotective Actions of_Paullinia pinnata_L.," Pharmacognosy Journal, vol. 2, no. 10, pp. 345-350, 2010.

[138] I. K. Voukeng, V. P. Beng, and V. Kuete, "Antibacterial activity of six medicinal Cameroonian plants against Grampositive and Gram-negative multidrug resistant phenotypes," BMC Complementary and Alternative Medicine, vol. 16, no. 1 , p. $388,2016$.

[139] J. Hutchinson and J. M. Dalziel, "Flora of West Tropical Africa," II. Millbank, London Crown Agents for Oversea Government and Administration, vol. 1963, no. 4, pp. 221-221, 1963.

[140] H. M. Burkil, The Useful Plants of West Tropical Africa, vol. 1985, Royal Botanical Garden, UK, KEW, 2nd edition, 1985.

[141] B. Dayananda, M. Birhanetensay, and M. Arunabha, "Antiulcer properties of herbal drugs: a review," International Journal of Biomedical Research, vol. 8, no. 3, pp. 116-124, 2017.

[142] O. A. Ojiako and C. U. Igwe, "A Time-Trend Hypoglycemic Study of Ethanol and Chloroform Extracts of Strophanthus hispidus," Journal of Herbs, Spices \& Medicinal Plants, vol. 15, no. 1, pp. 1-8, 2009.

[143] E. O. Agbaje and M. S. Fageyinbo, "Evaluating antiinflammatory activity of aqueous root extract of Strophanthus hispidus DC. (Apocynaceae)," International Journal of Applied Research in Natural Products, vol. 4, no. 4, pp. 7-14, 2012.

[144] C. Agyare, A. S. Dwobeng, N. Agyepong et al., "Antimicrobial, Antioxidant, and Wound Healing Properties of Kigelia africana (Lam.) Beneth. and Strophanthus hispidus DC.,"
Advances in Pharmacological Sciences, vol. 2013, Article ID 692613, 10 pages, 2013.

[145] I. O. Ishola, O. Awodele, I. A. Oreagba, A. A. Murtala, and M. C. Chijioke, "Antinociceptive, anti-inflammatory and antiulcerogenic activities of ethanol root extract of Strophanthus hispidus DC (Apocynaceae)," Journal of Basic and Clinical Physiology and Pharmacology, vol. 24, no. 4, pp. 277-286, 2013.

[146] B. A. Mba, C. S. Alisi, and A. C. Ene, "Antioxidant Properties and Protective Effect of Aqueous Anti-Ulcer Drug (AQAUD) against Aspirin-induced Gastric Ulcers in Albino Rats," Asian Journal of Biochemistry, Genetics and Molecular Biology, vol. 3, no. 2, pp. 9-21, 2020.

[147] M. Afzal, B. Al-Hadidi, M. Menon, J. Pesek, and M. S. Dhami, "Ginger: An Ethnomedical, Chemical and Pharmacological Review," Drug Metabolism and Drug Interactions, vol. 18, no. 3-4, pp. 159-190, 2001.

[148] P. V. Sharma and G. P. Sharma, Kaiyadeva Nighantu, vol. 2009, Chaukhamba orientalia, Varanasi, 1st edition, 2009.

[149] K. G. C. Dissanayake, W. A. L. C. Waliwita, and R. P. Liyanage, "A review on medicinal uses of Zingiber officinale (ginger)," International Journal of Health Sciences and Research, vol. 10, no. 6, 2020.

[150] C. A. Anosike, O. Obidoa, U. S. L. Ezeanyika, and M. M. Nwuba, "Anti-inflammatory and anti-ulcerogenic activity of the ethanol extract of ginger (Zingiber officinale)," African Journal of Biochemistry Research, vol. 3, no. 12, pp. 379384, 2009.

[151] A. Srivastava, Y. N. Shukla, and S. Kumar, "Recent development in plant derive antimicrobial constituents-a review," Journal of Applied Research on Medicinal and Aromatic Plant, vol. 22, no. 2, pp. 349-405, 2000.

[152] O. F. Omoya and F. C. Akharaiyi, "Mixture of honey and ginger extract for antibacterial assessment on some clinical isolates," International Journal on Pharmaceutical and Biomedical Research, vol. 2, no. 1, pp. 39-47, 2011.

[153] D. V. Derle, K. N. Gujar, and B. S. H. Sagar, "Adverse effects associated with the use of nonsteroidal antiinflammatory drugs: An overview," Indian Journal of Pharmaceutical Sciences, vol. 68, no. 4, pp. 409-414, 2006.

[154] S. U. Zaman, M. M. Mirje, and S. Ramabhimaiah, "Evaluation of the anti-ulcerogenic effect of Zingiber officinale (ginger) root in rats," International Journal of Current Microbiology and Applied Sciences, vol. 3, no. 1, pp. 347-354, 2014.

[155] A. I. Airaodion, U. Ogbuagu, E. O. Ogbuagu et al., "Investigation of aqueous extract of Zingiber officinale root potential in the prevention of peptic ulcer in albino rats," International Journal of Research and Innovation in Applied Science (IJRIAS), vol. 4, no. 2, pp. 64-67, 2019.

[156] S. B. Olaleye and E. O. Farombi, "Attenuation of indomethacin- and $\mathrm{HCl} /$ ethanol-induced oxidative gastric mucosa damage in rats by kolaviron, a natural biflavonoid ofGarcinia kola seed," Phytotherapy Research, vol. 20, no. 1, pp. 14-20, 2006.

[157] J.-K. Shin, J. H. Park, K. S. Kim, T. H. Kang, and H. S. Kim, "Antiulcer Activity of Steamed Ginger Extract against Ethanol/HCl-Induced Gastric Mucosal Injury in Rats," Molecules, vol. 25, no. 20, p. 4663, 2020.

[158] R. S. Pawar, U. K. Patil, R. Gadekar, P. K. Singour, and P. K. Chaurasiya, "A potential of some medicinal plants as an antiulcer agents," Pharmacognosy Reviews, vol. 4, no. 8, pp. 136146, 2010. 